ÉGYPTE

monde arabe

\section{Égypte/Monde arabe}

$34 \mid 1998$

Droits d'Égypte : histoire et sociologie

\title{
Hilary Lewis Ruttley and Chibli Mallat (eds), Commercial Law in the Middle East
}

\section{Maurits S. Berger}

\section{(2) OpenEdition}

\section{Journals}

Édition électronique

URL : https://journals.openedition.org/ema/1560

DOI : 10.4000/ema. 1560

ISSN : 2090-7273

\section{Éditeur}

CEDEJ - Centre d'études et de documentation économiques juridiques et sociales

\section{Édition imprimée}

Date de publication : 31 décembre 1998

Pagination : 291-294

ISSN : 1110-5097

\section{Référence électronique}

Maurits S. Berger, « Hilary Lewis Ruttley and Chibli Mallat (eds), Commercial Law in the Middle East »,

Égypte/Monde arabe [En ligne], 34 | 1998, mis en ligne le 08 juillet 2008, consulté le 07 juillet 2022.

URL : http://journals.openedition.org/ema/1560; DOI : https://doi.org/10.4000/ema.1560

Ce document a été généré automatiquement le 7 juillet 2022.

Tous droits réservés 


\title{
Hilary Lewis Ruttley and Chibli Mallat (eds), Commercial Law in the Middle East
}

\author{
Maurits S. Berger
}

\section{RÉFÉRENCE}

Hilary Lewis Ruttley, Chibli Mallat (eds), Commercial Law in the Middle East, London : Graham \& Trotman, 1995

Hani Sarie-Eldin, Consortia Agreements in the International Construction Industry, with Special Reference to Egypt, London : Kluwer Law International, 1996

1 It is peculiar that law in the Middle East is of interest to western academics if it concerns Islamic law as such, family law and court procedural law, and to western lawyers if it concerns commercial law. The two hardly ever meet. An exception to the rule is probably Chibli Mallat, who moves on both terrains. The book Commercial Law in the Middle East, written whith Hilary Lewis Ruttley, is one of his many publications.

2 The book is a collection of articles which gives a clear overview of commercial laws in Egypt, Lebanon, Saudi Arabia, Bahrein and Pakistan. The additional specific subjects, such as Islamic banking and construction contracts, are to the point and informative. The choice of countries, however, seems to reflect English business interests only. The commercial laws of Libya, Morocco, Palestine, Jordan or Syria, which all belong to the same region, are not included. Also, a discussion of the role of the MENA conferences would have been a valuable and interesting contribution. In this respect, the relevance of the articles on the Gulf Crisis claims proceedings against Iraq is not clear in the context of commercial law.

3 As the introduction to Commercial Law in the Middle East says, the book is indeed « by and for practicing lawyers. » It will prove very useful for the lawyer who, for the first time, sets foot in any of the countries discussed. It will give him or her insight into the basic 
legal frameworks and concepts. But for more detailed information, these kinds of regional books are insufficient. The discussion of a specific subject, such as Hani SarieEldin's Consortia Agreements in the International Construction Industry, would have much more practical value.

Are these books, therefore, for lawyers only ? I think not. What becomes apparent from publications such as these, and which is interesting for academics, lawyers and businessmen, is that commercial law in this region appears to be a field of law that is hardly touched by Islamic law. Commercial Law in the Middle East is ' the most interesting in this respect and deserves more attention.

5 All the countries discussed in this book are either self-proclaimed Islamic states in which Islamic law is applicable, or have at least constitutions that prescribe adherence to Islamic law. Saudi Arabia claims that it is enough to declare Islamic law applicable without implementing it by means of statutory laws. Pakistan and Iran claim to have Islamic (statutory) laws, and countries such as Egypt claim that their laws are not conflicting with Islamic law. It is a matter of hot debate in the (legal) communities of these countries whether their laws and legal system are Islamic enough. This puts much political pressure on the legislators.

6 With commercial law, however, this pressure hardly exists. Nabil Saleh, in his article on the Gulf states, argues that this is due to the commercial interests of both legislators and those who advocate strict adherence to Islamic law. Islam is fine, but business must go on, it seems. This becomes apparent from the following features of commercial laws (which include corporate laws) of the countries discussed.

7 First, they are all statutory laws. This even applies to Saudi Arabia, where sharî́a law officially covers commercial transactions and where the judges theoretically have vast discretionary powers to interpret sharî'a law. In his article, however, Frank Vogel argues that these judges are actually quite conservative andunwilling to deal with more modern commercial matters, which prompts central authorities to regulate specific areas of commercial law by Royal Decree.

8 Second, all these statutory laws are based on the Egyptian codes, which are based on the French model. An exception is Pakistan, which has laws based on English common law. In addition, many contractual arrangements governing the import, export, carriage and insurance of goods to and from the Middle East will most probably have an English law aspect, as Keith Michel points out in his article. The same applies to international construction contracts, which are usually governed by the so-called standard FIDIC contracts. Also, Middle Eastern countries are bound by the international treaties and conventions to which they are signatories, such as the Treaty of 1952 for Reciprocal Enforcement of Judgements, and the New York Convention of 1958 regarding the Recognition and Enforcement of Foreign Arbitration Awards, which are both signed by most Middle Eastern countries.

9 Third, most of the countries discussed in these publications are in the midst of reorganizing their economy. The end of the Second Gulf War in.1991 was a turning point in this respect. From that moment on, Egypt and many Gulf countries have been amending and promulgating commercial and related laws to attract foreign investors. The most striking feature of these amendments is that foreigners are allowed to have a majority share in national companies. 
Fourth, one of the few typical Islamic elements of commercial law in the Middle East, Islamic banking, does not appear to have a disrupting effect on regional commerce. It has indeed spread rapidly in the region, and has taken a considerable share in the market (percentages of twenty to thirty percent are mentioned), as well as significant amounts of deposits. But the growing pains and free-for-all attitude of Islamic banking in the 1980s has been replaced by government involvement and regulatory control. The activities of Islamic banks are also nowadays mostly limited to trade finance through the Islamic finance contract of murâbaha, which implies short-term and low-risk investment. Finally, Islamic banking is still in development. In his article on interest (ribâ) in Iran, for instance, Ansari-Pour shows that riba is still a hotly debated issue. Interest is forbidden, but Iranian banks are allowed to charge administrative fees and (according to some court rulings) calculate the rate of inflation. Moreover, exceptions are possible for foreign transactions, under certain conditions specified by the Council of Guardians.

11 In their introduction, Ruttley and Mallat write that "the forgotten tradition " (i.e. Islamic law) only appears occasionally in commercial law, such as in Islamic banking. The disregard for this tradition, they argue, «brings unease to commercial law and affects the stability of transactions. » This view is not reflected in the articles. On the contrary, the picture that emerges from these articles reflects exactly whatRuttley and Mallat merely considered one of the historical features of commerce in the Middle East, namely «the centrality of trade.» Islamic law seems to be put to the service of commerce, not the other way around.

\section{AUTEUR}

MAURITS S. BERGER

University of Amsterdam 